\title{
Implementing guidelines in general practice care
}

\author{
Richard Grol
}

By changing nothing we hang to what we understand, even if it is the bars of our own jail - JOHN LE CARRE, The Russia House, 1990

Developing guidelines for general practice care, based on good research and on valuable clinical experience, is increasingly seen as one of the crucial tools for achieving high quality care. ${ }^{1}$ Despite efforts to set standards, guidelines, or protocols implementing them in practice has generally received little attention.

Guidelines are not self implementing. ${ }^{2}$ It is well known that new and valuable information; new scientific results; and, in particular, new consensus guidelines or protocols reach only part of the target group. ${ }^{3-5}$ Even if doctors are well informed about what to do, they often do not perform according to their knowledge or skills, ${ }^{3-9}$ and the relation between their attitude towards certain expected behaviour and actual performance is generally weak.

Ideas about implementing guidelines and standards in general practice tend to be naive. The interventions or strategies are often restricted in circulation to publication in (scientific) journals and to continuing medical education by means of lectures or group discussions. Many general practitioners (GPs) do. not read this information. Only half of them will attend meetings for continuing medical education, and only those on topics considered as interesting to them. Often only reinforcement of existing ideas is achieved. Research usually shows that the effect of continuing medical education on actual performance in practice is marginal. ${ }^{6} 7$ 10-12

Classic approaches to implementing new information fail because, firstly, too little attention is given to the specific barriers to change in certain groups of doctors and practices. Also too much effort is spent on improving knowledge and attitudes and too little on improving skills and actual behaviour; too little is known about interventions and programmes that are really effective in changing GPs' performance. In this paper I shall explore the current views and research on implementing guidelines and suggest some recommendations on methods and approaches to quality improvement in general practice. I shall discuss in more detail some of the general principles of promoting change in clinical care highlighted by Stocking in this journal. ${ }^{13}$

\section{Implementing guidelines as a step by step process}

To disseminate and implement consensus guidelines and new information in general practice performance several steps must be taken. Views on changing behaviour from various discipline ${ }^{14-20}$ may help in identifying these steps. They are summmarised as follows.

- Orientation - attention and becoming informed about the existence of new guidelines

- feeling interest, commitment

- Insight - understanding the guidelines

- awareness of (gaps in) own performance, persuasion of the need to change

- Acceptance-positive attitude to the new guidelines

- intention to change, confidence in success

- Change - actual implementation in practice, experimentation

- recognition of positive outcomes, maintenance of change.

Each step in the process may be attended by specific problems or barriers. It is important to be aware of these, to study them, and to adapt the interventions to overcome them. ${ }^{19}$ These barriers may be studied by examining the literature; surveys of physicians, other care providers, and patients; or structured group interviews with representatives from the target population. ${ }^{21}$ An observation of the actual practice performance in some of the practices may also improve the understanding of specific problems of implementing changes. The message is "know your target group."22 Someone who wants to implement guidelines must "zip himself into the clients' skins and see their situation through their eyes."23 Barriers may exist because of either the characteristics of the GP or those of the practice setting.

BARRIERS WITHIN GPS

Barriers within the doctor can be in competence, motivation and attitude, and personal characteristics.

Competence - GPs with competence barriers do not keep up with the literature or read a rather one-sided selection of new information; they do not follow continuing medical education programmes and are poorly informed about new developments and insights. They may forget new information before implementing it. ${ }^{64}$ They may be unaware of gaps in their performance or underestimate them. ${ }^{25}$ They lack the necessary skills to perform the expected behaviour ${ }^{26}$ or may not have the opportunity to experiment with new behaviour. ${ }^{27}$

Motivation, attitude - Some GPs may see more disadvantages than advantages or may expect negative consequences from the 
proposed guidelines. ${ }^{14}$ They may be satisfied with their performance and not see the need to change. ${ }^{27}{ }^{28}$ They may not view the guidelines as feasible or applicable or not see any possibility of implementing them. ${ }^{27}$ They may not trust the initiators and the promoters of the proposed change, regarding them as "academics" not as practitioners. ${ }^{14} 2930$ Perhaps they do not accept the guidelines because of lack of involvement in consensus discussions or of opportunity to "reinvent" and adapt the proposals for change in their own situation. ${ }^{14}$ The guidelines may also not fit into their existing views, opinions, and values about work..$^{514}$

Personal characteristics - Several of the doctors' personal characteristics may be important.

Age and experience - Older doctors generally have more problems with accepting new information and guidelines than younger doctors. ${ }^{51-34}$

Membership of professional organisations usually results in being better informed and more inclined to accept innovations. ${ }^{53233}$

Learning style - Doctors differ in their learning style ${ }^{3536}$; some learn about new insights by reflection or by theoretical introduction, others by experience or demonstration.

Self confidence - Doctors' confidence in performing adequately according to the guidelines and that their behaviour will have the expected outcomes may differ. ${ }^{18} 2037$

Willingness to change - Some doctors are more open to new information, are more prepared to take risks, and are more inclined to experiment with new behaviour than others. ${ }^{14}$ Thus "early adopters," "middle majority," and "late adopters" may be distinguished: these groups may differ in their needs, personal characteristics, values, communication behaviour, and learning styles. $^{3813}$

BARRIERS WITHIN PRACTICE SETTING

GPs do not work entirely independently. Decisions come about in discussions and negotiations with others (practice staff, patients, other care providers) who may have a powerful influence on the doctors'

Table 1 Barriers to implementing new guidelines

\begin{tabular}{|c|c|}
\hline Steps & Barriers, problems \\
\hline Orientation & $\begin{array}{l}\text { No reading or selective reading, no } \\
\text { continuing medical education } \\
\text { No contact with colleagues } \\
\text { No needs or interest }\end{array}$ \\
\hline Insight & $\begin{array}{l}\text { Insufficient knowledge or skills } \\
\text { No awareness of gaps in own routines } \\
\text { Overestimation of own performance }\end{array}$ \\
\hline Acceptance & $\begin{array}{l}\text { Seeing more disadvantages than advantages } \\
\text { Change not seen as feasible } \\
\text { Not feeling involved, committed } \\
\text { Expecting problems, negative consequences } \\
\text { Negative attitude of opinion leaders in } \\
\text { network } \\
\text { Change requires extra time or money }\end{array}$ \\
\hline Change & $\begin{array}{l}\text { Seeing no concrete alternatives } \\
\text { Inadequate practice premises } \\
\text { No confidence in success } \\
\text { Forgetting, reverting to old routines } \\
\text { Negative outcomes of change, no } \\
\text { reinforcement }\end{array}$ \\
\hline
\end{tabular}

performance. The same is true for all kinds of practical and structural factors related to the general practice setting. ${ }^{39}$

Social factors - Patients may have different opinions and requirements; they may refuse to cooperate or the doctor may be afraid that they will not cooperate. ${ }^{40}$ Colleagues, practice staff, other care providers in the practice or in the area, managers or opinion leaders, and key persons within the doctor's social network may also disagree with the proposed change. ${ }^{29} 41$ The networks of some GPs are conservative and resistant to new ideas and guidelines. $^{6}$ One problem may be that the physician works solo and is seldom involved in professional interaction. Soloists seem to have less information and seem to change less than practitioners who collaborate closely with other care providers. ${ }^{5} 3342$

Structural, logistic, and organsiational factors The prerequisites for change may not be available in the practice ${ }^{641}$ or the guidelines may demand an extra investment of time or money. ${ }^{43}$ The proposed change can interfere with existing practice routines or requires alterations in practice management. ${ }^{14}$ Finally, local infrastructures, rules, or laws may interfere with the proposed change. ${ }^{19}$

Each of these barriers to change may play a part in preventing the adoption of guidelines and the achievement of necessary improvements in general practice care. Table 1 shows how they relate to the steps of implementing new guidelines. In the Netherlands the Dutch College of General Practitioners has been involved in national standard setting since 1987. A rigorous procedure, lasting 1-1.5 years, has been used to develop guidelines with a scientific basis and broad acceptance among GPs. Since 1989,25 sets of guidelines have been published in a scientific journal. ${ }^{5}$ One guideline is concerned with the management of a distorted ankle. It says that GPs may carry out the diagnosis and treatment in their own practice; $x$ ray examinations as well as referrals to surgeons and physiotherapists are seldom necessary. A survey of a randomised sample of 500 Dutch GPs (response rate 64\%) was

Table 2 Problems experienced by 320 Dutch GPs in complying with national guidelines for managing distorted ankle (revised version of original table ${ }^{43 a}$ )

\begin{tabular}{lccc}
\hline & \multirow{2}{*}{$\begin{array}{c}\% \\
\text { Of respondents }\end{array}$} & \multicolumn{2}{c}{ Factor analysis } \\
\cline { 3 - 4 } & & $I$ & $I I$ \\
\hline $\begin{array}{l}\text { Patients often go directly to } \\
\text { the hospital }\end{array}$ & 83 & 0.60 & 0.05 \\
$\begin{array}{l}\text { Patients have other wishes } \\
\begin{array}{l}\text { Patients have doubts about } \\
\text { the competence of the GP }\end{array}\end{array}$ & 69 & 0.67 & 0.17 \\
$\begin{array}{l}\text { I do not have bandaging } \\
\text { skills }\end{array}$ & 54 & 0.76 & 0.09 \\
$\begin{array}{l}\text { Physiotherapist often takes } \\
\text { over the treatment }\end{array}$ & 53 & 0.08 & 0.54 \\
$\begin{array}{l}\text { My colleagues perform } \\
\text { differently }\end{array}$ & 38 & 0.40 & 0.14 \\
$\begin{array}{l}\text { Insufficient research evidence } \\
\text { available }\end{array}$ & 36 & 0.10 & 0.53 \\
$\begin{array}{l}\text { Extra workload on weekend } \\
\text { services in general practice }\end{array}$ & 28 & 0.11 & 0.58 \\
$\begin{array}{l}\text { Insufficient knowledge of this } \\
\text { condition }\end{array}$ & 24 & 0.03 & 0.79 \\
\hline
\end{tabular}

$\mathrm{I}=$ Barriers within GPs (competence, attitudes).

II = Barriers within practice setting (social and organisational factors). 


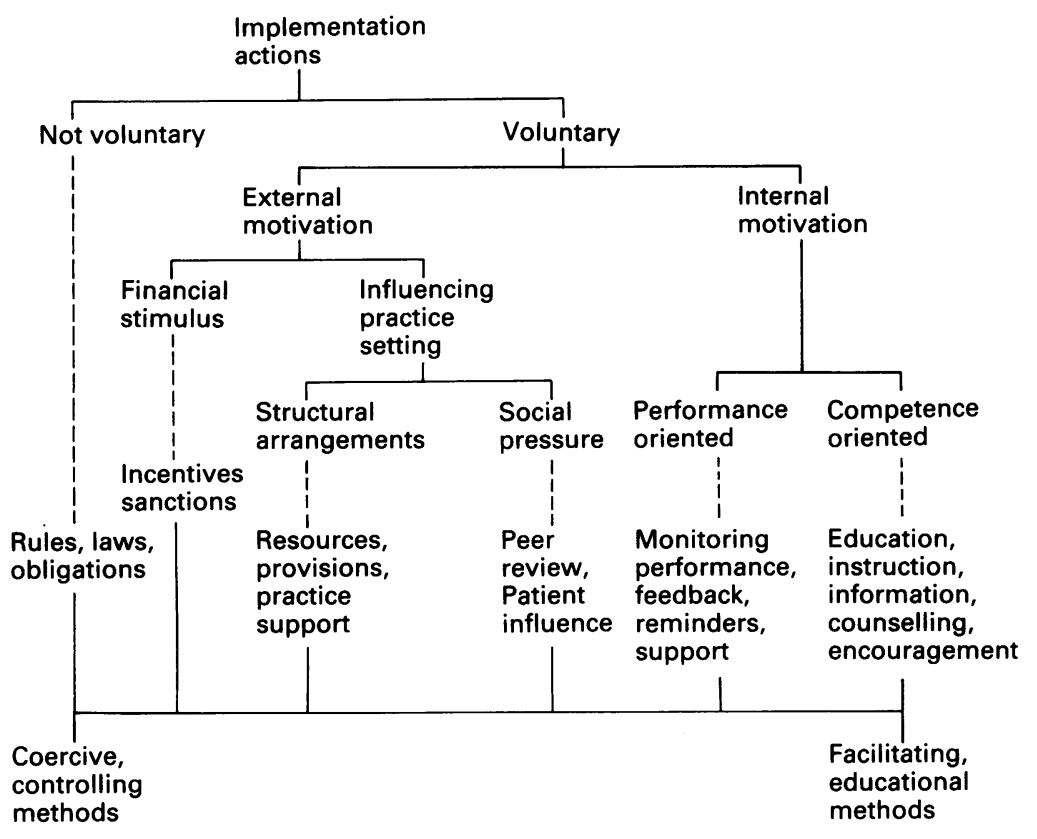

* Adapted from Van Woerkom ${ }^{45}$, Damoiseaux ${ }^{46}$

Factors involved in successful implementation of new information and guidelines in practice $^{\star}$

performed to evaluate the barriers and problems that GPs experienced in complying with these national guidelines. In particular, barriers related to the network of the GP seemed to inhibit implementation of the guidelines. $^{43 a}$ Most respondents saw the attitude of the patients in this case as a problem in complying with the recommendations. Clustering of the problems and barriers by a factor analysis (varimax rotation) supports the existing distinction between barriers in the GP and barriers in the practice setting (table 2).

\section{Effective interventions}

There is no one ideal strategy or intervention. Since many different factors and barriers play a part in the change process and doctors and practices differ in experience, needs, and learning styles a variety and combination of methods is required to implement guidelines successfully. ${ }^{13} 3144$ Intensive, long lasting interventions, in which the "message" is repeated again and again are necessary. ${ }^{7} 104546$ Effective implementation of guidelines requires written as well as personal approaches; use of mass media as well as small group and individually directed approaches; and interventions aimed at changing

Table 3 Features of different groups of GPs and approaches to implementing practice guidelines

\begin{tabular}{|c|c|c|c|}
\hline & Early adopters & Majority & Late adopters \\
\hline Salient features & $\begin{array}{l}\text { Opinion leaders, } \\
\text { models }\end{array}$ & Deliberate, sceptical & Traditional, isolated \\
\hline $\begin{array}{l}\text { Motivation for } \\
\text { change }\end{array}$ & $\begin{array}{l}\text { Intrinsically, seeing } \\
\text { advantages }\end{array}$ & $\begin{array}{l}\text { Social needs, } \\
\text { relation with peers }\end{array}$ & $\begin{array}{l}\text { Extrinsically, } \\
\text { pressure, power }\end{array}$ \\
\hline Actions directed to & Cognitions & Motivation, attitudes & Behaviour \\
\hline $\begin{array}{l}\text { Actions, } \\
\text { interventions }\end{array}$ & $\begin{array}{l}\text { Written methods, } \\
\text { scientific arguments, } \\
\text { credible sources }\end{array}$ & $\begin{array}{l}\text { Personal sources, } \\
\text { opinion leaders, peer } \\
\text { activities, } \\
\text { reinforcement by } \\
\text { social network }\end{array}$ & $\begin{array}{l}\text { Regulations, laws, } \\
\text { incentives or } \\
\text { sanctions, practical } \\
\text { resources and } \\
\text { provisions }\end{array}$ \\
\hline
\end{tabular}

Sources: Stocking, ${ }^{13}$ Rogers, ${ }^{14}$ Green et al. ${ }^{38}$ knowledge, skills, and attitudes as well as those addressing performance and behaviour. ${ }^{11} 18$ 47-49 These interventions should be directed towards existing barriers and problems with implementation ${ }^{89194150}$ and are preferably carried out on various levels that is, nationally as well as locally and at a practice level.

A COMBINATION OF INTERVENTIONS

Methods to disseminate and implement guidelines in practice might range from a predominantly facilitating approach to more coercive approaches (figure). ${ }^{15} 5152$ Generally, both educational and coercive approaches may be required to achieve lasting implementation. The more positive a target group is about the recommendations or the more it perceives a need for it, the more an educational and facilitating approach might be sufficient. However, when doctors are rather resistant or when the guidelines demand some investment from them other policies might also be required to complete the intervention. Bearing in mind the diversity of the target group, that any target group is composed of "innovators" and "early adopters", "majority," and "late adopters," several different interventions and strategies are likely to be more effective in different subgroups. ${ }^{13}{ }^{38}$ For the early adopters written scientific information might be sufficient; the majority will be particularly sensitive to peer influences and the opinions of key persons in the social network; and the late adopters might need an extra stimulus in the form of resources and provisions for their practices, incentives or official statements, and rules by responsible bodies (table 3 ).

The methods of implementing guidelines in general practice follow a parallel dimension to the one above; table 4 summarises their effectiveness. Reviews on the subject are those by Haynes et $a l,{ }^{10}$ Haynes and Walker, ${ }^{53}$ Horder et al, ${ }^{31}$ Lomas and Haynes, ${ }^{7}$ Soumerai et $a l,{ }^{48}$ and Mugford et al. ${ }^{54}$

Written educational materials - Evidence from many well controlled studies indicates that articles in journals, printed educational materials, drug bulletins, educational brochures, and the use of mass media alone to

Table 4 Effectiveness of interventions designed to change routines in general practice

\begin{tabular}{|c|c|c|}
\hline & & Effect \\
\hline \multirow{2}{*}{$\begin{array}{l}\text { Facilitating, } \\
\text { educational } \\
\text { methods } \\
\qquad\end{array}$} & $\begin{array}{l}\text { Mailed educational materials, } \\
\text { journals, mass media }\end{array}$ & - \\
\hline & $\begin{array}{l}\text { Continuing medical education, group } \\
\text { education, courses, tutorials }\end{array}$ & $+1-$ \\
\hline 1 & $\begin{array}{l}\text { Face to face education, individual } \\
\text { instruction }\end{array}$ & + \\
\hline I & Audit and feedback (by computer) & $+1-$ \\
\hline 1 & Reminders (by computer) & + \\
\hline I & $\begin{array}{l}\text { Peer reviews, quality circles, practice } \\
\text { visiting }\end{array}$ & + \\
\hline I & Patient influence & $?$ \\
\hline 1 & $\begin{array}{l}\text { Structural arrangements (provisions, } \\
\text { staff) }\end{array}$ & $?$ \\
\hline$\downarrow$ & Barriers to performance & $+1-$ \\
\hline Coercive, & Incentives or sanctions & $+/-$ \\
\hline $\begin{array}{l}\text { controlling } \\
\text { methods }\end{array}$ & $\begin{array}{l}\text { Rules, laws, obligations, certification, } \\
\text { contracts }\end{array}$ & $?$ \\
\hline
\end{tabular}


disseminate new information have hardly any effect on medical practice. ${ }^{3} 71124485255-59$

Continuing medical education and group education such as courses, lectures, tutorials, skills training, etc, may improve knowledge and skills if carried out over a protracted period. ${ }^{612}{ }^{45}$ In some studies they proved to be insufficient in changing performance whereas in others they affected practice behaviour. ${ }^{11}$ When giving information to doctors was combined with small group discussions, selfinstruction materials, and tracing individual gaps in performance the effect was improved. ${ }^{60-63}$

Face to face education and individual instruction - These include brief one to one educational visits by trained colleagues or counsellors, which may be effective in changing doctors' performance, ${ }^{56-59} 64-67$ particularly in influencing prescribing patterns. ${ }^{48}$ Especially, they are more effective than other educational interventions. ${ }^{68}{ }^{69}$ Visits by respected and competent colleagues ("the best friend model") are held to be more successful than visits by non-medical colleagues. $^{59} 70$

Audit and feedback reinforce performance by collecting data and supplying positive or negative information on (gaps in) performance. Some studies show that monitoring practice performance and giving feedback are effective in changing medical practice, ${ }^{25}$ 71-81 "individualised or personal feedback" proving to be superior to group feedback. $^{82-84}$ Computers may have an important supporting role in feedback on performance. ${ }^{53} 5578$ However, other studies on the effects of feedback were less positive. ${ }^{85-88}$ Feedback probably is most influential when it is presented directly after the performance and it is continual to prevent practitioners reverting to their old routines. ${ }^{89} 90$ In particular, audit and feedback by respected peers as part of a more comprehensive strategy will be effective in introducing and implementing guidelines. ${ }^{91} 92$

Reminders - Before or while carrying out certain activities, the doctor is reminded (by an assistant, a computer, or other) that certain behaviour should (or should not) be performed. Although this is an area of developing research, some studies show that reminders may contribute to influencing doctors' performance, particularly when combined with other methods. ${ }^{93-102}$

Peer review, quality circles and practice visits With these methods influence and pressure of persons in the social network are intended to effect a change in practice routines. Most people are sensitive to opinions, values, and signals from their peers, particularly when they act as opinion leaders or key persons. In approaching a district, a health centre, or a doctor to implement changes in performance, cooperation from key persons should be sought first. ${ }^{29} 456566$ These individuals may serve as models in convincing other doctors. ${ }^{37}$ When applied to motivating general practitioners in Ireland to participate in peer review groups this approach resulted in $90 \%$ participation. In several studies peer review in groups of doctors proved to be effective in changing practice routines. ${ }^{82} 839192103-105$ In these studies (peer) feedback was used as a part of a broader more comprehensive approach, in which various methods and interventions (criteria setting, quality circles, educational methods, group discussions, feedback, etc) were combined ("shotgun approach"). A promising peer review method is the practice visit by (teams of)colleagues, which proved to be acceptable in the United Kingdom, Canada, New Zealand, and Netherlands, particularly for testing (new) trainers in vocational training. ${ }^{105-109}$ Unfortunately, results from well designed studies of its effects are not yet available.

Patient influence can be brought to bear on practice routines and implementing guidelines - for instance, through complaints procedures, ${ }^{110}$ informing patients about new guidelines, ${ }^{99}$ and surveys among patients on their needs, satisfaction, and health status and feedback to practitioners. ${ }^{11-115}$ Although research evidence is not clear yet, this approach seems to be promising.

Structural arrangements and provisions - In some situations barriers to implementing guidelines are mainly related to practical aspects of the setting in which the change has to be implemented - for example, staff, workload, practice management, financial resources, provisions in the practice, or structural arrangements. In these cases giving temporary or continuous support might be decisive in successful implementation of necessary change in practice performance. Cohen, for instance, found that doctors' examination of diabetic patients' feet increased threefold when a practice assistant instructed the patients in advance to remove their shoes and socks. ${ }^{116}$ Involving specially trained staff looks promising. ${ }^{67117} 118$ The use of computer programmes to support decisions and activities in general practice care may be very powerful in influencing the implementation of new guidelines. ${ }^{119} 120$ More research in this area is required.

Barriers to performance - A particular form of structural arrangement is the use of barriers to force practitioners to follow guidelines, by which the doctor must ask approval or submit justification before a specific performance is accepted or remunerated. ${ }^{121}$ Changing the laboratory test form influenced the test ordering in some studies ${ }^{122123}$ but not in others. ${ }^{124}$

Incentives or sanctions - From the 1970s onwards bonuses have been offered to doctors in many countries, in particular for carrying out less expensive procedures. Opinions of the value of financial incentives and sanctions for implementing new information in practice differ widely. Physicians were found to be responsive to financial incentives and income differentials. ${ }^{125}$ Hillman et al concluded that some, but not all, financial incentives influence behaviour of physicians. ${ }^{126}$ However, the effects gradually diminish because of familiarity. When physicians have a vested 
interest in specific procedures they will perform them more often. ${ }^{127} 128$ In a study of the effects of a financial bonus for obstetricians who reduced the hospital stay of patients the outcome was a significant reduction in the duration of admissions. ${ }^{129}$ However, conflicting results were found from other studies. ${ }^{79} 85$ 130-132 Horder et al presented screening for cervical carcinoma and immunisation procedures by GPs in the United Kingdom as successful examples of this strategy, both of which increased after a financial reward for these procedures was introduced $^{31}$; however, a decline in the number of deliveries was also recorded despite an incentive payment.

Obligations, rules, and laws - Finally, implementing guidelines for general practice may be achieved by coercion or obligation through rules and laws. These methods are used by governments or insurers in virtually all countries - for instance, the prescription of treatment is restricted in many countries; accreditation and recertification are similar methods. Regulation of this kind may be one of the most powerful methods of influencing behaviour, but the long term results are not yet clear.

Developing reliable, valid, sensitive, and feasible assessment and recertification tools and procedures will require additional research. Besides, even if we succeed in developing them, there are other, more fundamental, problems related to coercive methods and formal recertification of doctors based on quality guidelines. These are well described by Berwick. ${ }^{133}$ Based on experience in industry, he argues that identification of poorly performing doctors ("bad apples") will lead to fear, frustration, and anger in the target group. Under pressure they will probably collaborate but will also try to sabotage or cheat the assessment. Moreover, such an assessment procedure will be expensive and inefficient, while it is directed only at a small proportion of the target group. He favours an approach of "continuous improvement" directed to all doctors and practice workers. Research is required to study the validity of this approach.

Having identified potentially effective interventions and having determined that the best approach is a combination of methods and interventions directed to specific barriers to change, we might ask who should be involved in the implementation of guidelines and changes in general practice and on what level should it be initiated? Table 5 summarises the possible approaches. On various levels the aims and the persons and organisations having the main responsibility for improving patient care in general practice are different. Linking the strategies on the various levels to each other will increase the likelihood that necessary changes will be implemented in practice.

\section{Conclusions and recommendations}

Changing medical practice to improve patient care probably is the most complex step in a quality assurance system: "In my opinion, effectiveness in inducing behavioural change is the most important, yet least understood problem in quality monitoring today," was the opinion of Donabedian. ${ }^{134}$ Many of the routines in practice are based on automatic reactions. Thus GPs do not differ fundamentally from patients who have problems following the prescriptions of their doctor or changing their lifestyle. ${ }^{135}$

However, problems related to change do not only concern people. Often the work setting is

Table 5 Framework for implementing guidelines in general practice

\begin{tabular}{|c|c|c|c|}
\hline Where? (Level) & Aim & Who? & How? \\
\hline $\begin{array}{l}\text { Central } \\
\text { (national, } \\
\text { regional) }\end{array}$ & $\begin{array}{l}\text { Creating favourable conditions } \\
\text { Infrastructure } \\
\text { Developing methods and } \\
\text { programmes }\end{array}$ & $\begin{array}{l}\text { Professional organisations } \\
\text { Government } \\
\text { Insurers } \\
\text { Organisations for continuing } \\
\text { medical education and quality } \\
\text { assurance } \\
\text { Research institutes and } \\
\text { academic departments }\end{array}$ & $\begin{array}{l}\text { Publication of research results } \\
\text { and guidelines in journals } \\
\text { Mailing of guidelines } \\
\text { Conferences, courses, tutorials } \\
\text { on guidelines } \\
\text { Good instruction materials for } \\
\text { guidelines } \\
\text { Financial incentives or sanctions } \\
\text { Procedures for accreditation and } \\
\text { relicensing }\end{array}$ \\
\hline Local & $\begin{array}{l}\text { Local arrangements } \\
\text { Local continuing medical } \\
\text { education } \\
\text { Influencing local structures }\end{array}$ & $\begin{array}{l}\text { Local doctors } \\
\text { Specialists } \\
\text { Other disciplines } \\
\text { Local committees and boards } \\
\text { Facilitators }\end{array}$ & $\begin{array}{l}\text { Local continuing medical } \\
\text { education, group education on } \\
\text { guidelines } \\
\text { Peer review } \\
\text { Opinion leaders, key persons } \\
\text { Consensus meetings with } \\
\text { colleagues } \\
\text { Arrangements with other care } \\
\text { providers }\end{array}$ \\
\hline Practice & $\begin{array}{l}\text { Organising quality improvement } \\
\text { with all practice members }\end{array}$ & $\begin{array}{l}\text { Doctors } \\
\text { Other practice workers } \\
\text { Facilitators }\end{array}$ & $\begin{array}{l}\text { Setting practice objectives } \\
\text { Journals, library } \\
\text { Practice based audit and } \\
\text { feedback } \\
\text { Involving facilitators for } \\
\text { individual instruction } \\
\text { Structural arrangements } \\
\text { Practice visits } \\
\text { Quality circles } \\
\text { Patient surveys }\end{array}$ \\
\hline Individual & $\begin{array}{l}\text { Individual continuing education } \\
\text { and change }\end{array}$ & $\begin{array}{l}\text { Doctors } \\
\text { other practice workers }\end{array}$ & $\begin{array}{l}\text { Reading } \\
\text { Following courses, tutorials } \\
\text { Self audit } \\
\text { Reminders } \\
\text { Feedback } \\
\text { Skills training }\end{array}$ \\
\hline
\end{tabular}


a crucial part of the problem. ${ }^{133}$ Thus achieving change in medical practice is an issue that should be addressed in a creative and varied manner. Analysis of the current literature teaches us several important lessons.

- A process of continuous improvement should be planned on several levels - that is, on a central, local, practice, and individual level

- A combination of interventions, methods, and programmes should be developed; these should be directed to the specific barriers to change of specific target groups in the profession

- Face to face instruction, assessment, and feedback by well respected peers (in peer review groups, quality circles, or practice visits), combined with practical support (facilitators, provisions, and financial stimuli), seem to be particularly effective in improving the quality of care.

However, much more research on the effectiveness of interventions is necessary, in particular on the role of patients and computers in implementing new guidelines and procedures in general practice. The studies currently available often have methodological shortcomings, the interventions are difficult to compare, and most lack information on health outcomes. $^{710} 48$

Grol R. The development of guidelines for general practice care. $\mathrm{Br} \mathcal{f}$ Gen Pract (in press)

2 Field $\mathrm{M}$, Lohr $\mathrm{E}$, eds. Clinical practice guidelines. Directions for a new program. Washington: National Directions for a new prog
Academic Press, 1990 .

Kosecoff J, Kanouse D, Rogers W, McCloskey I Winslow C, Brook R. Effects of the National Institutes Winslow C, Brook R. Effects of the National Institutes of Health Consensus Development Program

physician practice. $\mathcal{F} A M A$ 1987;258:2708-13.
Fowler G, Fuller A, Mant D, Jones L. The "help your Fowler G, Fuller A, Mant D, Jones L. The "h patient stop" initiative. Lancet 1989;i:1253-5. Grol R. National standard setting for quality of care in general practice: attitudes of general practitioners an response to a set of standards. $\mathrm{Br} \mathcal{f}$ Gen Pract 1990;40:361-4.

6 Sanazaro P. Determining physicians' performance. Continuing medical education and other interacting variables. Evaluation and the Health Professions 1983;2:197-210

7 Lomas J, Haynes R. A taxonomy and critical review of tested strategies for the application of clinical practice tested strategies for the app "ication of clinical practice recommendations. from Serv 1988;4:77-95.

Pommerenke F, Weed D. Physician compliance: improving skills in preventive medicine practices. $\mathrm{Am}$ Fam Physician 1991;43:560-8.

9 McPhee S, Bird J, Jenkins C, Fordham D. Promoting cancer screening. A randomized controlled trial of three interventions. Arch Intern Med 1989;149: 1866-72.

10 Haynes R, Davis D, McKibbon A, Tugwell P. A critical appraisal of the efficacy of continuing medical education. $7 A M A$ 1984;251:61-4.

11 Stein I. The effectiveness of continuing medical education: eight research reports. $f$ Med Educ 1981;56:103-10

12 Evered D, Williams $H$. Postgraduate education and the doctor. BM7 1980;280:626-8.

13 Stocking B. Promoting change in clinical care. Quality in Health Care 1992;1:56-60.

14 Rogers E. Diffusion of innovations. New York: Free Press, 1988.

15 Zaltman G, Duncan R. Strategies for planned change. New York: Wiley, 1977

16 McGuire W. Improving the health status of adults by inducing changes in institutional and personal behaviour. Prev Med 1984;13:299-319.

17 Fishbein H, Ajzen I. Beliefs, attitude, intention and behaviour: an introduction to theory and research. Reading, Massachusetts: Addison Wesley, 1975.

18 Bandura A. Social foundation of thought and action. Englewood Cliffs: Prentice Hall, 1986.

19 Flora J, Farquhar J. Methods of message design: experiences from the Standford Five City Project. Scand 7 Prim Health Care 1988;1(suppl):41-80.
20 Strecher V, McEvoy De Vellis B, Becker M, Rosenstock IM. The role of self-efficacy in achieving health behavior change. Health Educ $Q$ 1986;13:73-91.

21 Ramirez A, Shepperd J. The use of focus groups in health care research. Scand f Prim Health Care 1988;1(suppl): $81-90$

22 Kotler P, Roberto E. Social marketing. Strategies for changing public behavior. New York: Free Press, 1989.

23 Kaegi L. Dissemination and testing of clinical practice guidelines move to top of meeting agendas for AHCPR and Society for Medical Decision Making. $Q R B$ 1991;17:402-12.

24 Evans C, Haynes R, Birkett N. Does a mailed continuing education program improve physician performance? fAMA 1986;225:501-4.

25 Rosser W. Using the perception-reality gap to alter prescribing patterns. Fournal of Medical Education 1983;58:728-32.

26 Asbaugh D, McLean R. Continuing medical education: the philosophy and the use of audit. $\mathscr{A} A M A$ 1976;13:1485-8.

27 Geertsma $R$, Parker $R$, Krauss Whitbourne S. How physicians view the process of change in their practice physicians view the process of change in their practice $722-61$.

28 Scott A. Continuing education: more or better? $N$ Engl 7 Med 1976;295:444-5.

29 Greer A. The state of the arts versus the state of the science. The diffusion of new medical technologies into practice. International fournal of Technology Assessmen in Health Care 1988;4:5-26.

30 Bohannan R, LeVeau B. Clinicians' use of research findings. Phys Ther 1986;66:45-50.

31 Horder J, Bosanquet N, Stocking B. Ways of influencing the behaviour of general practitioners. $f R$ Coll Gen Pract 1986;36:517-21.

32 Bridgestock $M$. Social theory and measures of the quality of medical care in general practice. Soc Sci Med $1979 ; 13 ; 269-75$.

33 Freiman $M$. The rate of adoption of new procedures among physicians. Med Care 1985;23:939-45.

34 Stange K, Kelly R, Chao J, Zyzanski SJ, Shank JC, Jaen $\mathrm{C}$, et al. Physician agreement with US Preventive Services Task Force recommendations. $f$ Fam Pract 1992;34:409-16.

35 Whitney M, Caplan R. Learning styles and instructional preferences of family practice physicians. Fournal of Medical Education 1978;53:684-6.

36 Lewis A, Bolden $\mathrm{K}$. General practitioners and their learning styles. F $R$ Coll Gen Pract 1989;39:187-9.

37 Parcel G, Eriksen M, Lovato C, Gottlieb NH, Brink SG, Green LW. The diffusion of school-based tobacco-use prevention programs: project description and baseline data. Health Education Research 1989;4:111-24.

38 Green L, Gottlieb N, Parcel G. Diffusion theory extended and applied. In: Advances in health education and promotion. Vol 3. Greenwich, Connecticut: JAI and promotion.

39 Sang-O-Rhee Relative importance of physicians' personal and situational characteristics for the quality personal and situational characteristics for the qua
of patient care. $\mathcal{H}$ Health Soc Behav 1977; 18:10-5.

40 Smith $R$. The f Health Soc Behav 1977;18:10-5; 1335-8.

41 Fineberg $\mathrm{H}$. Effects of clinical evaluation on the diffusion of medical technology. In: Institute of Medicine. Assessing medical technologies. Washington: National Academic Press, 1985.

42 Williamson P. The adoption of new drugs by doctors practising in group and solo practice. Soc Sci Med 1975;9:233-6.

43 Lurie N, Manning W, Peterson C, Goldberg GA, Phelps CA, Lillard L. Preventive care: do we practise what we preach? Am $\mathcal{f}$ Public Health 1987;77:801-4.

$43^{\mathrm{a}}$ Grol R, Claessen A, Van der Velden J, Heerdink $H$. Kwaliteit van zorg by enkeldistorie: invoering van een standaard. Huisarts en Wetenschap 1991;34:30-4.

44 Kottke T, Battista RN, DeFriese G, Brekke ML Attributes of succesful smoking cessation intervention in medical practice. $\mathcal{F} A M A$ 1988;259:2883-9.

45 Eisenberg J. Physician utilization. The state of research about physician practice patterns. Med Care 1985;23:461-83.

46 Ferguson K, Caplan R, Williamson P. Factors associated with behavior change in family physicians after CME presentations. Fournal of Medical Education 1984; 59:662-6

47 Winkler J, Lohr K, Brook R. Persuasive communications and medical technology assessment. Arch Intern Med $1985 ; 145 \cdot 314-7$.

48 Soumerai S, McLaughin T, Avorn J. Quality assurance for drug prescribing. Quality Assurance in Health Care 1990;2:37-58.

49 Sackett D, Haynes R, Tagwel P. Clinical epidemiology. Boston: Little, Brown, 1985 .

50 Mann $R$ Why patient participation groups stop functioning: general practitioners' viewpoint. $B M \mathcal{F}$ 1985;290;209-11.

51 Woerkom C van. Voorlichting als beleidsinstrument: nieuw en krachtig? Inaugurale rede. Wageningen: en krachtig? Inaugurale rede. Wa

52 Damoiseaux V. Listen, listen en lasten van massamediale Damoiseaux V. Listen, listen en lasten van massamediale
voorlichting [Thesis]. Maastricht: University of Maastricht, 1991.312 pp.

53 Haynes R, Walker $\mathrm{C}$. Computer-aided quality assurance: a critical approach. Arch Intern Med 1987;147: 1297-301. 
54 Mugford M, Banfield P, O'Hanlon $M$. Effects of feedback of information on clinical practice: a review. BMF 1991;303:398-402. , Warshaw G, Gehlbach SH, Bobula JA Muhlbaier LH, Parkerson GR. Improving hypertension control: impact of computer feedback and physician education. Med Care 1981;19:843-54. vorn J, Soumerai S. Improving drug-therapy decision hrough educational outreach. $N$ Engl $₹ \mathrm{Med}$ 1983;308:1457-63. , Effect of government and commercial warnings on reducing prescription misuse: the case of propoxyphene. $A m \mathcal{J}$

58 Schaffner W, Ray W, Federspiel C, Miller W. Improving antibiotic prescribing in office practice: a controlled trial of three educational methods. $\mathscr{f} A M A$ 1983;250:1728-32

59 Ray W, Blazer D, Schaffner W, Federspiel C, Fink R. Reducing long-term diazepam prescribing in office practice: a controlled trial of educational visits. $\mathfrak{F} A M A$ 1986;256:2536-9.

60 White C, Albanese M, Brown D, Caplan R. The effectiveness of continuing medical education in changing the behavior of physicians, caring for patients with acute myocardial infarction. A controlled with acute myocardial infarction. A controlled

61 Inui T, Yourbee E, Williamson J. Improved outcomes in hypertension after physician tutorials: a controlled trial. hypertension after physician tutorials
Ann Intern Med 1976;84:646-51.

62 Klein L, Charace P, Johannes R. Effect of physician tutorials on prescribing patterns of graduate physicians. fournal of Medical Education 1981;56:504-11.

63 Sibley J, Sackett P, Neufeld V, Gerrard B, Rudnick KV, Fraser W. A randomized trial of continuing medical education. $N$ Engl F Med 1982;306:511-5.

64 Soumerai S, Avorn I. Predictors of physicians' prescribing change in an educational experiment to improve medication use. Med Care 1987;25:210-21.

65 Stross J, Bole G. Evaluation of a continuing education program in rheumatoid arthritis. Arthritis Rheum 1980;23:846-9.

66 Perera D, Lo Gerfo J, Shulenberger E, Yivisaker JT, Kirz HL. Teaching sigmoidoscopy to primary care physicians: a controlled study of con

67 Fullard E, Fowler G, Gray M. Promoting prevention on primary care: controlled trial of low technology, low cost approach. BMF 1987;294:1080-5.

68 Dietrich A, O'Connor G, Keller A, Carney PA, Levy D, Whaley FS, et al. Cancer: improving early detection and prevention. A community practice randomised trial. $B M F$ 1992;304:687-91.

69 Cockburn J, Ruth D, Silagy C, Dobbin M, Reid Y, Scollo M. Randomised trial of three approaches for marketing smoking cessation programmes to Australian general practitioners. $B M \mathcal{F}$ 1992;304:691-4.

70 Allsop J. Changing primary care: the role of facilitators. London: Kings' Fund Centre, 1990.

71 Nelson A Orphan data and the unclosed loop: dilemma in PSRO and medical audit. $N$ Engl $\mathcal{f} M e d$ 1976;295:617-20.

72 Gehlbach S, Wilkinson W, Hammond W, Clapp NE, Finn AL, Taylor WJ, et al. Improving drug prescribing in a primary care practice. Med Care 1984;22: 193-201.

73 Fleming $D$, Lawrence $M$. Impact of audit on preventive measures. $B M \Im$ 1983;287:1852-4.

74 Frame P, Kowalich B, Dewellyn A. Improving physician compliance with a health maintenance protocol. 7 Fam Pract 1984;19:341-4.

75 Berwick D, Coltin K. Feedback reduces test use in a Health Maintenance Organization. $\mathcal{F} A M A$ 1986;255: $1450-4$.

76 Pop P, Winkens R. A diagnostic centre for general practitioners: individual feedback on diagnostic practitioners: individual feedback on

77 Sanazaro P, Worth $\mathrm{R}$. Concurrent quality assurance in hospital care. Report of a study by private initiative in hospital care. Report of a study by private
PSRO. $N$ Engl $₹$ Med 1978;298:1171-8.

78 McAlister N, Covvey H, Tong K, Lee A, Wigle ED. Randomised controlled trial of computer assisted management of hypertension in primary care. $B M \mathcal{F}$ 1986;293:670-4

79 Martin A, Wolf M, Thibodeau L, Dzau V, Braunwald E. A trial of two strategies to modify the test-ordering
behavior of medical residents. New Engl $\mathcal{J}$ Med 1980;303:1330-6.

80 Creighton P, Evans A. Audit of practice based cervical smear programme: completion of the cycle. $B M F$ 1992;304:963-6.

81 Gabbay J, Layton A. Evaluation of audit of medical inpatient records in a district general hospital. Quality in Health Care 1992;1:43-7.

82 Winickoff RN, Coltin $\mathrm{K}$, Morgan M, Buxbaum RC, Barnett G. Improving physician performance through peer com

83 Sommers L, Sholtz R, Shepherd R, Starkweather DB. Physician involvement in quality assurance. Med Care 1984;12:1115-34.

84 Winkens R, Pop P, Grol R, Kester ADM, Knottnerus JA. Effect of feedback on test ordering behaviour of general practitioners. $B M \mathcal{F}$ 1992;304:1093-6.
85 Schroeder S, Meyers L, McPhee S, Showstack JA, Simborg DW, Chapman SA, et al. The failure of physician as a cost containment strategy: report of a prospective controlled trial at a university hospital. $\mathscr{f} A M A$ 1984;252:225-30.

86 Everett G, De Blois S, Chang P, Holets T. Effect of cost education, cost audits and facility chart review on the use of laboratory services. Arch Intern Med use of laborator

87 Cohen D, Jones P, Lettenberg B, Neuhauser D. Does cost information availability reduce physician test usage? Med Care 1982;20:286-92.

88 Parrino T. The non-value of retrospective peer comparison feedback in containing hospital antibiotic costs. Am $\mathcal{F}$ Med 1989;86:442-8.

89 Harris C, Fry J, Jarman B, Woodman E. Prescribing - a case for prolonged treatment. $\mathcal{F} R$ Coll Gen Pract 1985;35:284-7.

90 Rhyne R, Gehlbach S. Effect of an educational feedback strategy on physician utilization of thyroid function panels. F Fam Pract 1979;5:103-7.

91 Grol R, Mokkink H, Schellevis F. The effects of peer review in general practice. $\mathcal{F} R$ Coll Gen Pract 1988;38:10-3.

92 North of England Study of Standards and Performance in General Practice. Medical audit in general practice. I. Effects on doctors' clinical behaviour for common childhood conditions. BMF 1992;304:1480-4.

93 Barnett G, Winickoff $R$, Morgan $M$, Zielstorff RD. A computer-based monitoring system for follow-up of elevated blood pressure. Med Care 1983;21:400-9.

94 Barnett G. Winickoff R, Dorsey J, Morgan MM, Lurie RS. Quality assurance through automated monitoring and concurrent feedback using a computer-based medical information system. Med Care 1978;16: 962-70.

95 McDonald C. Protocol-based computer reminders, the quality of care and the non-perfectibility of man. $N$ Engl f Med 1976;295:1351-5.

96 Tierney W, Hui S, McDonald C. Delayed feedback of physician performance vs immediate reminders to physician performance vs immediate reminders to
perform preventive care: effects on physician compliance. Med Care 1986;24:659-66.

97 Rogers J, Haring O, Wortman P, Watson RA, Goetz JP. Medical information systems: assessing impact in the areas of hypertension, obesity and renal disease. Med Care 1982;20:63-74.

98 Rogers J, Haring O, Goetz J. Changes in patient attitudes following the implementation of a medical information system. QRB 1984;10:65-74.

99 Davidson R, Fletcher S, Retchin S, Duh S. A nurseinitiated reminder system for the periodic health inamination Implementation and evaluation. Arch Intern Med 1984;144:2167-70.

100 Cheney C, Ramsdell J. Effect of medical records checklists on implementation of periodic health measured. Am $\mathcal{F}$ Med 1987;83:129-36.

101 Tierney W, Miller M, McDonald C. The effect on test ordering of informing physicians of the changes for
outpatient diagnostic tests. New Engl $\mathscr{J}$ Med outpatient diagnost

102 Cummings $K$, Frisof K, Long M, Hrynkienich G. The effects of price information on physicians' test-ordering behavior: ordering of diagnostic tests. Med Care 1982;20:293-301.

103 Verby J, Holden P, Davies R. Peer review of consultations in primary care: the use of audiovisual recordings. $B M F$ 1979;i:1686-8

104 Deuschle J, Alvarez B, Logsdon DN, Stahl WM, Smith H. Physician performance in a prepaid health-plan: results of the peer review program of the health insurance plan of Greater New York. Med Care 1982;2:127-42.

105 Grol R, Mesker P, Schellevis F, eds. Peer review in general practice. Nijmegen: Department of General Practice, practice. Nijmegen: Department

106 Royal College of General Practitioners. What sort of a doctor? Assessing quality of care in general practice. London: RCGP 1985. (Report from general practice 23.

107 Borgiel A, Williams J, Bass M, Dunn EV, Evenden MK Lamont CT, et al. Quality of care in family practice: does residency training make a difference? Can Med Assoc $\mathcal{F}$ 1989;140:1035-43.

108 McAuley R, Henderson $H$. Results of the peer assessment program of the College of Physicians and Surgeons of Ontario. Can Med Assoc 1984;131:557-61.

109 Royal College of General Practitioners. Fellowship by 50.)

110 Donaldson L, Cavanagh J. Clinical complaints and their handling: a time for change? Quality in Health Care 1992;1:21-5.

111 Cleary P, Edgman-Levitan S, Roberts M, Keroy L Karapanos G, McMullen W, Roberts $M$, Keroy L, hospital care. $O R B$ 1989;15:172-9.

112 Kazis L, Callahan L, Meenan R, Pincus T. Health status reports in the case of patients with rheumatoid arthritis. reports in the case of patients with

113 Rubenstein L, Calkins D, Young R, Cleary PD, Fink A Kosenoff J, et al. Improving patient function: randomized trial of functional disability screening. Ann Intern Med 1989;111:836-40. 
114 Nelson E, Wasson J, Kirk J. Assessment of function in routine clinical practice: description of the COOPchart method and preliminary findings. Fournal of Chronic Diseases 1987;40(suppl):55-63.

115 Nelson E, Larson C, Davies A, Gustafson D, Ferreira ME, Ware JE. The patient comment card: a system to gather customer feedback. $Q R B$ 1991;17:278-85.

116 Cohen S. Potential barriers to diabetes care. Diabetes Care 1983;6:499-500.

117 Harker P, Leopoldt H, Robinson J. Attaching community psychiatric nurses to general practice. $\mathcal{f} R$ Coll Gen Pract 1976;26:66-71.

118 Mandel J, Franks D, Dickinson J. Improving physician compliance with preventive medicine guidelines. f Fam Pract 1985;21:223-4.

119 Whiting-O'Keefe Q, Simborg D, Epstein W, Warger H. A computerized summary medical record system can provide more information than the standard medical record. $\mathcal{F A M A} 1985 ; 254: 1185-92$.

120 Garret L, Hammond W, Sted W. The effects of computerized medical records on provider efficiency and quality of care. Methods Inf Med 1986;25:151-7.

121 Kroenke K, Hanley J, Copley J, Matthews JI, Davis CA Foulks CJ, et al. Improving house staff ordering of three common laboratory tests: reduction in test ordering need not result in underutilization. Med Care 1987;25:928-35.

122 Sussman E, Goodwin P, Rosen H. Administrative chang and diagnostic test use. Med Care 1984;22:569-72.

123 Zaat J, Van Eyk, Bonte H. Laboratory test form design influences test ordering by general practitioners in the Netherlands. Med Care 1992;30:189-98.

124 Fowkes F, Evans K, Hartley G, Nolan DJ, Roberts CJ, Davies ER, et al. Multicentre trial of four strategies to reduce use of radiological test. Lancet 1986;i:367-70.
125 Hurley J. Simulated effects of incomes-based policies on the distribution of physicians. Med Care 1990;28:221-38.

126 Hillman A, Pauly M, Kerstein J. How do financial incentives affect physicians' clinical decisions and the incentives affect physicians' clinical decisions and the financial performance of health maintain

127 Childs A, Hunter E. Non-medical factors influencing use of diagnostic $\mathbf{x}$ ray by physicians. Med Care

128 Lundberg $\mathrm{G}$. How will changes in physician payment by Medicare influence laboratory testing? $\mathscr{f} A M A$ 1989;258:803-8.

129 Sims P, Cabral D, Daley W, Alfano L. The incentive plan: an approach for modification of physician behavior. Am F Public Health 1984;74:150-2.

130 Lohr K, Brook R, Kamberg C, Goldberg GA, Leibowitz $A$, Keesey J, et al. Use of medical care in the Rand health insurance experiment: diagnosis- and servicespecific analysis in a randomized controlled trial. Med Care 1986;24(suppl):31-8.

131 Schroeder S Strategies for reducing medical costs by changing physicians' behavior: efficacy and impact on changing physicians' behavior: efficacy and impact on quality of care. International fournal

132 Barer M, Evans R, Labell R. The frozen north: controlling physician costs to control fees - the Canadian experience in hhysician payment and medical technology under the Medicare Programme. Washington: Office of Technology Assessment, 1985.

133 Berwick D. Continuous improvement as an ideal in health care. N Engl f Med 1989;320:53-6.

134 Donabedian A. Comments. In: Pendleton D, Schofield T, Marinker $M$, eds. In pursuit of quality. London: Royal College of General Practitioners, 1986

135 Goldman L. Changing physicians' behavior. New Engl f Med 1990;232:1524-5. 